\title{
Corticotropin-releasing factor and its receptors in the brain of rats with insulin and corticosterone deficits
}

\author{
Qingling Huang, Elena Timofeeva and Denis Richard \\ Merck Frosst/CIHR Research Chair in Obesity, Centre de Recherche de l'Hôpital Laval, Hôpital Laval, 2725 Chemin Sainte-Foy, Québec, G1V 4G5 Canada \\ (Requests for offprints should be addressed to D Richard; Email: denis.richard@crhl.ulaval.ca)
}

\begin{abstract}
The expression of genes encoding corticotropin-releasing factor (CRF) and its receptor type-1 (CRF $\left.{ }_{1} \mathrm{R}\right)$ and type-2 $\alpha$ $\left(\mathrm{CRF}_{2} \mathrm{R}\right)$ has been studied in the brain of rats with streptozotocin (STZ)-induced diabetes and adrenalectomy (ADX). Diabetic rats had a lower body weight compared to control rats. Food and water intake were increased in diabetic rats and decreased in ADX animals. The plasma corticosterone levels measured at the nadir of the circadian rhythm were significantly higher in diabetic rats compared to non-diabetic animals. STZ-diabetic rats demonstrated an induction of expression of CRF mRNA in the magnocellular part of the paraventricular hypothalamic nucleus (PVN) and in the supraoptic nucleus (SON), whereas the CRF transcript in the parvocellular PVN was significantly lower in rats with insulin deficiency. ADX strongly triggered the expression of CRF mRNA in the parvocellular neurons of the PVN in both nondiabetic and diabetic rats, and it decreased magnocellular CRF mRNA in diabetic animals. The expression of the $\mathrm{CRF}_{1} \mathrm{R}$ in the parvocellular and magnocellular PVN and in the SON was induced by diabetes and decreased after ADX. The levels of the $\mathrm{CRF}_{2} \mathrm{R}$ mRNA in the ventromedial hypothalamic nucleus $(\mathrm{VMH})$ were significantly lower in diabetic rats without any noticeable effects of ADX. The present results suggest opposite effects of insulin and corticosterone deficiency on the hypophysiotropic CRF and the $\mathrm{CRF}_{1} \mathrm{R}$ mRNA contents, whereas the expression of $\mathrm{CRF}_{2} \mathrm{R}$ was mostly related to insulin, but not to the corticosterone status.
\end{abstract}

Journal of Molecular Endocrinology (2006) 37, 213-226

\section{Introduction}

Corticotropin-releasing factor (CRF) is a 41-amino acid peptide widely distributed throughout the brain and particularly concentrated in the medial parvocellular division of the hypothalamic paraventricular nucleus (PVN, Vale et al. 1981, Sawchenko \& Swanson 1985). The CRF neurons of the parvocellular PVN are predominantly involved in the control of the hypothalamic-pituitary-adrenal (HPA) axis. Besides its stimulatory hypophysiotropic effects, CRF blunts energy balance through concomitantly reducing energy intake and augmenting energy expenditure (Richard et al. 2002). Central administration of CRF decreases food intake (FI) and food hoarding and increases thermogenesis (Rothwell 1990, Cabanac \& Richard 1995, Buwalda et al. 1997).

Homeostasis-threatening (stressful) conditions strongly affect the expression of CRF in the PVN. The pattern of CRF activation in the PVN depends on the nature of the applied stresses. Psychological or 'neurogenic' stresses ultimately increase CRF contents in the parvocellular PVN, whereas some 'systemic' stresses, such as the osmotic challenge, may decrease CRF expression in the parvocellular PVN and increase CRF transcript levels in the magnocellular PVN (Imaki et al. 1992, Sawchenko et al. 1996). The uncontrolled diabetes induced by streptozotocin (STZ) treatment can also be viewed as a model of chronic stress leading to increase in the HPA-axis basal activity, adrenal weight, plasma corticosterone levels, and urinary corticosterone excretion at the nadir of circadian activity (Dallman et al. 1994). In spite of a basal increase in the HPA-axis activity, STZ-treated rats demonstrate a reduced HPA-axis activation in response to administrations of CRF and adrenocorticotropin (ACTH), and a blunted response to the dexamethasone suppression test (Scribner et al. 1991, Chan et al. 2002). While the inhibitory and stimulatory effects of corticosterone and insulin respectively on the expression of PVN CRF have been acknowledged, the effect of STZ-induced diabetes on CRF expression is not entirely clear. Both, decrease and increase in CRF mRNA levels have been reported in the PVN after 4-8 days of STZ treatment (Sipols et al. 1995, Schwartz et al. 1997, Chan et al. 2001, 2005). It is noteworthy that the estimated CRF expressions in STZinduced diabetes have been done so far without taking into account the subdivisions of the PVN. As mentioned above, activation of the different parts of the PVN may vary according to the type of stress and some stresses may even change the expression sites of CRF within the PVN subnuclei (Viau \& Sawchenko 2002).

DOI: $10.1677 / j m e .1 .02103$ Online version via http://www.endocrinology-journals.org 


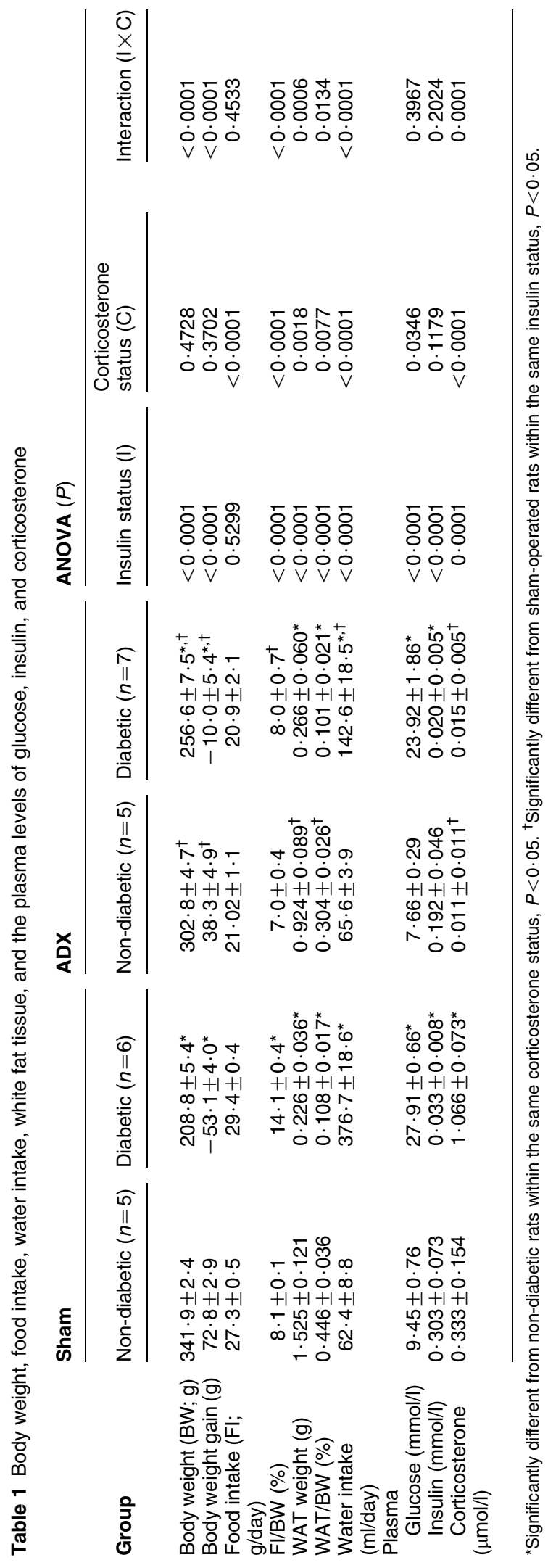

The central effects of CRF are mediated through two distinct high-affinity membrane receptors referred to as CRF type-1 ( $\mathrm{CRF}_{1} \mathrm{R}$, Perrin et al. 1993) and CRF type-2 $\alpha$ $\left(\mathrm{CRF}_{2} \mathrm{R}\right.$, Lovenberg et al. 1995) receptors. The $\mathrm{CRF}_{1} \mathrm{R}$ is widely distributed throughout the brain, anterior, and intermediate pituitary. Within the PVN, $\mathrm{CRF}_{1} \mathrm{R}$ mRNA is barely detectable under basal conditions, but can be readily induced by stressful stimuli (Rivest et al. 1995). The expression of the $\mathrm{CRF}_{2} \mathrm{R}$ is restricted to the particular limbic regions and to the ventromedial hypothalamic nucleus (VMH). Numerous data argue for a role of the VMH in control of FI and insulin secretion (King et al. 1984, Dube et al. 1999). There is evidence that the $\mathrm{CRF}_{2} \mathrm{R}$ is responsible for the anorectic effects of CRF (Vaughan et al. 1995). The $\mathrm{CRF}_{2} \mathrm{R}$ is highly expressed in the VMH under basal conditions, but the hyperphagia in obesity or fasting led to significant decrease of $\mathrm{CRF}_{2} \mathrm{R}$ levels in the $\mathrm{VMH}$, which might reduce the anorectic effects of CRF in these animals (Richard et al. 1996, Timofeeva \& Richard 1997). Alterations in the HPA-axis activity and FI in diabetic rats obviously imply both $\mathrm{CRF}_{1} \mathrm{R}$ and $\mathrm{CRF}_{2} \mathrm{R}$, but so far, there has been no report demonstrating the effects of insulin deficiency and combined interaction between diabetes and adrenalectomy (ADX) on the expression of the CRF receptors within the brain.

The present study was designed to further elucidate the effects of corticosterone and insulin deficiency on the expression of CRF and CRF receptors in order to clarify the possible role of the central CRF system in the persisting hyperactivity of the HPA axis and altered FI in diabetes.

\section{Materials and methods}

\section{Animals and treatments}

Male Sprague-Dawley rats weighing 260-270 g were purchased from the Canadian Breeding Laboratories (St Constant, QC, Canada). All rats were cared for and handled according to the Canadian Guide for the Care and Use of Laboratory Animals and the present protocol was approved by our institutional animal care committee. Animals were housed individually in wire-bottom cages suspended above absorbent paper, in temperaturecontrolled $\left(23 \pm 1{ }^{\circ} \mathrm{C}\right)$ and light-controlled (lights on between 0700 and $1900 \mathrm{~h}$ ) environment. Animals were randomly assigned to four groups: sham-operated nondiabetic rats, sham-operated diabetic rats, ADX nondiabetic rats, and ADX diabetic animals. Bilateral removal of the adrenals was achieved through two small lateral skin incisions made under isoflurane anesthesia. Sham-operated animals were treated in the same way as ADX animals except that the adrenals were not excised. STZ $(75 \mathrm{mg} / \mathrm{kg}$ ) or vehicle (citrate buffer, 
$\mathrm{pH} 4 \cdot 5)$ was intraperitoneally injected to shamoperated or adrenalectomized rats immediately after surgery. After surgery, all rats were given $0.9 \% \mathrm{NaCl}$ as a drinking fluid to prevent ADX-induced hyponatremia and to improve the glomerular filtration rate (DiTella et al. 1978, Will \& Barnett 1983). STZ-ADX rats received $5 \%$ glucose and $0.9 \% \mathrm{NaCl}$ as a drinking fluid for the first $24 \mathrm{~h}$ to prevent hypoglycemia and thereafter a solution containing solely $0.9 \% \mathrm{NaCl}$. Urine glucose was examined in the morning of the day following the injection of STZ with the reagent strips for urine analysis (Miles Canada Inc, Etobicoke, ON, Canada). The STZ-injected rats had more than 1-2\% urinary glucose and had the symptoms of polydipsia and polyuria. All rats were fed ad libitum a stock diet (Agway Prolab, Rat/Mouse/Hamster 1000 Formula) for the duration of experiment. FI, body weight (BW), and water intake (WI) were measured daily. All rats were sacrificed in the morning 8 days after the ADX surgery and/or STZ administration.

\section{Body weight, white adipose tissue weight, food intake, and water intake}

Measurements of BW, food, and WI determinations were performed every morning between 0700 and $0800 \mathrm{~h}$. FI and WI were measured by subtracting the remaining amounts of food or water from the fixed amount provided to rat. Food spillage was carefully calculated and accounted for in the measurements. At the end of experiment, epididymal white adipose tissue (WAT) was quickly dissected and immediately weighted. Blood was also sampled.

\section{Brain preparation}

Rats were anesthetized with $1.5 \mathrm{ml}$ mixture containing $20 \mathrm{mg} / \mathrm{ml}$ ketamine and $2.5 \mathrm{mg} / \mathrm{ml}$ xylazine. Without delay, they were intracardially perfused with $20 \mathrm{ml}$ ice-cold isotonic saline followed by $120 \mathrm{ml}$ paraformaldehyde $(4 \%)$ solution. The brains were removed at the end of perfusion and kept in paraformaldehyde for an additional period of 7 days. They were then transferred to a solution containing paraformaldehyde $(4 \%)$ and sucrose $(10 \%)$ before being cut $12 \mathrm{~h}$ later using a sliding microtome (Histoslide 2000, Reichert-Jung, Heidelberg, Germany). Brain sections were taken from the olfactory bulb to the brain stem. Thirty micrometer thick sections of brain were collected and stored at $-30{ }^{\circ} \mathrm{C}$ in a cold cryoprotecting solution containing sodium phosphate buffer $(50 \mathrm{mM})$, ethylene glycol (30\%), and glycerol $(20 \%)$.

\section{In situ hybridization histochemistry}

In situ hybridization histochemistry was used to localize $\mathrm{CRF}, \mathrm{CRF}_{1} \mathrm{R}$, and $\mathrm{CRF}_{2} \mathrm{R}$ mRNAs on tissue sections taken from the entire brain. The protocol used was largely
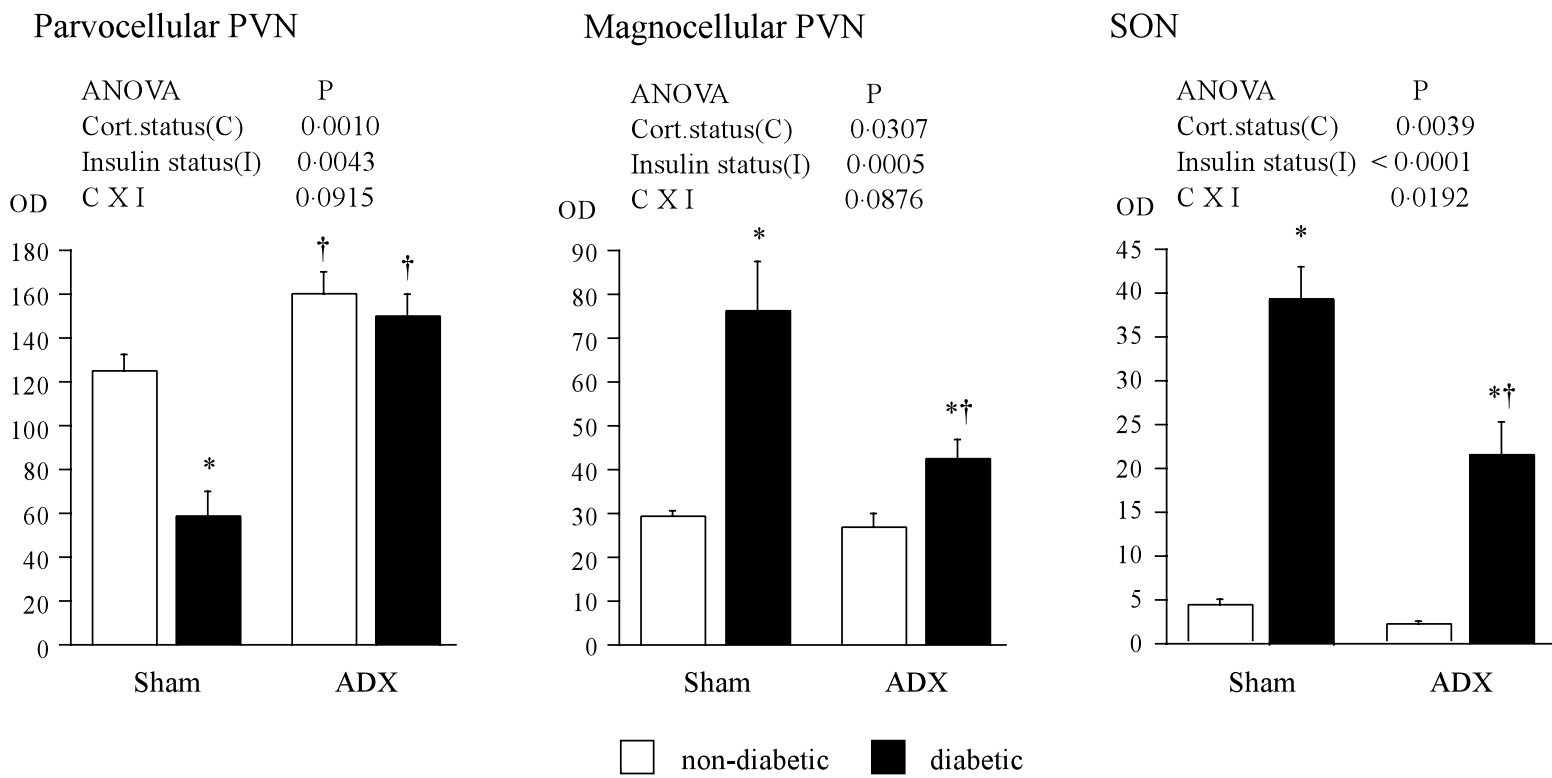

Figure 1 The optical densities (ODs) of the hybridization signals of CRF mRNA in the parvocellular and magnocellular parts of the PVN and in the supraoptic nucleus (SON). The main and interaction effects of insulin status (I; non-diabetic or diabetic) and corticosterone status (C; sham-operated or adrenalectomized) were determined using $2 \times 2$ ANOVA, followed by a posteriori Fisher's posterior list of significant difference. *Significantly different from non-diabetic rats within the same adrenal status; ${ }^{\dagger}$ Significantly different from sham-operated rats within the same insulin status, $P<0.05$. 
adapted from the technique described by Simmons $e t a l$. (1989). Briefly, one out of every five brain sections were mounted onto poly-L-lysine-coated slides and allowed to desiccate overnight under vacuum. The sections were then successively fixed for $20 \mathrm{~min}$ in paraformaldehyde (4\%), digested for $30 \mathrm{~min}$ at $37^{\circ} \mathrm{C}$ with proteinase $\mathrm{K}$ $(10 \mu \mathrm{g} / \mathrm{ml}$ in $100 \mathrm{mM}$ Tris- $\mathrm{HCl}$ containing $50 \mathrm{mM}$ EDTA, $\mathrm{pH} 8 \cdot 0$ ), acetylated with acetic anhydride $(0.25 \%$ in $0.1 \mathrm{M}$ triethanolamine, $\mathrm{pH} 8.0)$, and dehydrated through graded concentrations $(50,70,95$, and $100 \%$ ) of alcohol. After air drying for at least $2 \mathrm{~h}$,
$90 \mu \mathrm{l}$ hybridization mixture, which contains an antisense ${ }^{35}$ S-labeled cRNA probe $\left(10^{7}\right.$ c.p.m. $\left./ \mathrm{ml}\right)$, were spotted on each side. The slides were sealed under a coverslip and incubated overnight at $60{ }^{\circ} \mathrm{C}$ in the slide warmer. The next day, the coverslips were removed and the slides rinsed four times with $4 \times \mathrm{SCC}(0 \cdot 6 \mathrm{M} \mathrm{NaCl}$, $60 \mathrm{mM}$ trisodium citrate buffer, $\mathrm{pH} 7 \cdot 0$ ), digested for $30 \mathrm{~min}$ at $37^{\circ} \mathrm{C}$ with RNase-A $(20 \mu \mathrm{g} / \mathrm{ml}$ in $10 \mathrm{mM}$ Tris$500 \mathrm{mM} \mathrm{NaCl}$ containing $1 \mathrm{mM}$ EDTA), washed in descending concentrations of SSC $(2 \times, 10 \mathrm{~min} ; 1 \times$, $5 \mathrm{~min} ; 0.5 \times, 5 \mathrm{~min} ; 0.1 \times, 30 \mathrm{~min}$ at $60^{\circ} \mathrm{C}$ ) and

\section{Sham}


ADX

Non-diabetic

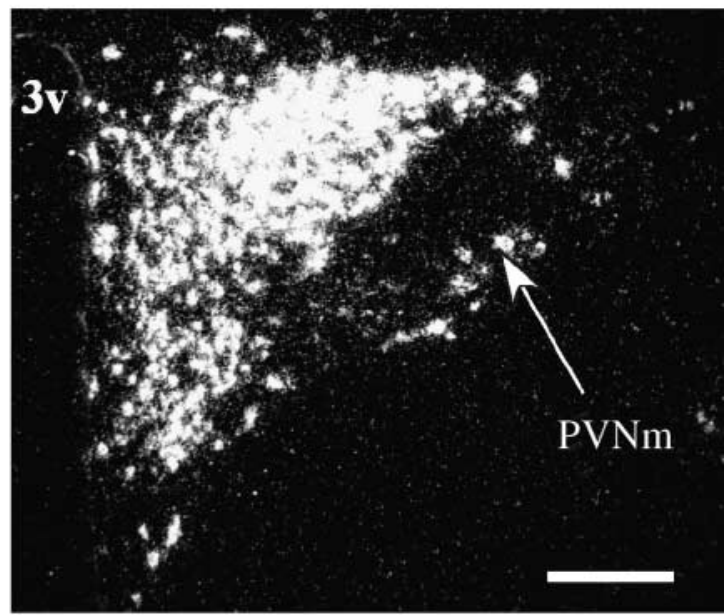

Diabetic

Figure 2 Dark field photomicrographs of coronal brain sections taken from the hypothalamic paraventricular nucleus, illustrating CRF mRNA. The brain sections (30 $\mu \mathrm{m}$ thick) were obtained from sham-operated (top panels) or adrenalectomized (ADX; bottom panels) non-diabetic (left panels) or diabetic (right panels) rats. PVNp and PVNm are the parvocellular and magnocellular parts of the PVN respectively; 3v, third ventricle. The scale bar corresponds to $200 \mu \mathrm{m}$. 
dehydrated through graded concentrations of alcohol. After a 2-h period of vacuum drying, the slides were exposed on an X-ray film (Kodak) for periods varying between 24 and $72 \mathrm{~h}$, depending upon the nature of the probes used. Once removed from the autoradiography cassettes, the slides were defatted in xylene and dipped in NTB2 nuclear emulsion (Eastman Kodak). Again depending on the probe used, the slides were exposed from 7 to 21 days, before being developed in D19 developer (Kodak) for $3.5 \mathrm{~min}$ at $14-15{ }^{\circ} \mathrm{C}$ and fixed in rapid fixer (Kodak) for 5 min. Finally, tissues were rinsed in running distilled water for $1-2 \mathrm{~h}$, counterstained with thionin $(0.25 \%)$, dehydrated through graded concentrations of alcohol, cleared in xylene, and coverslipped with DPX.

Sham
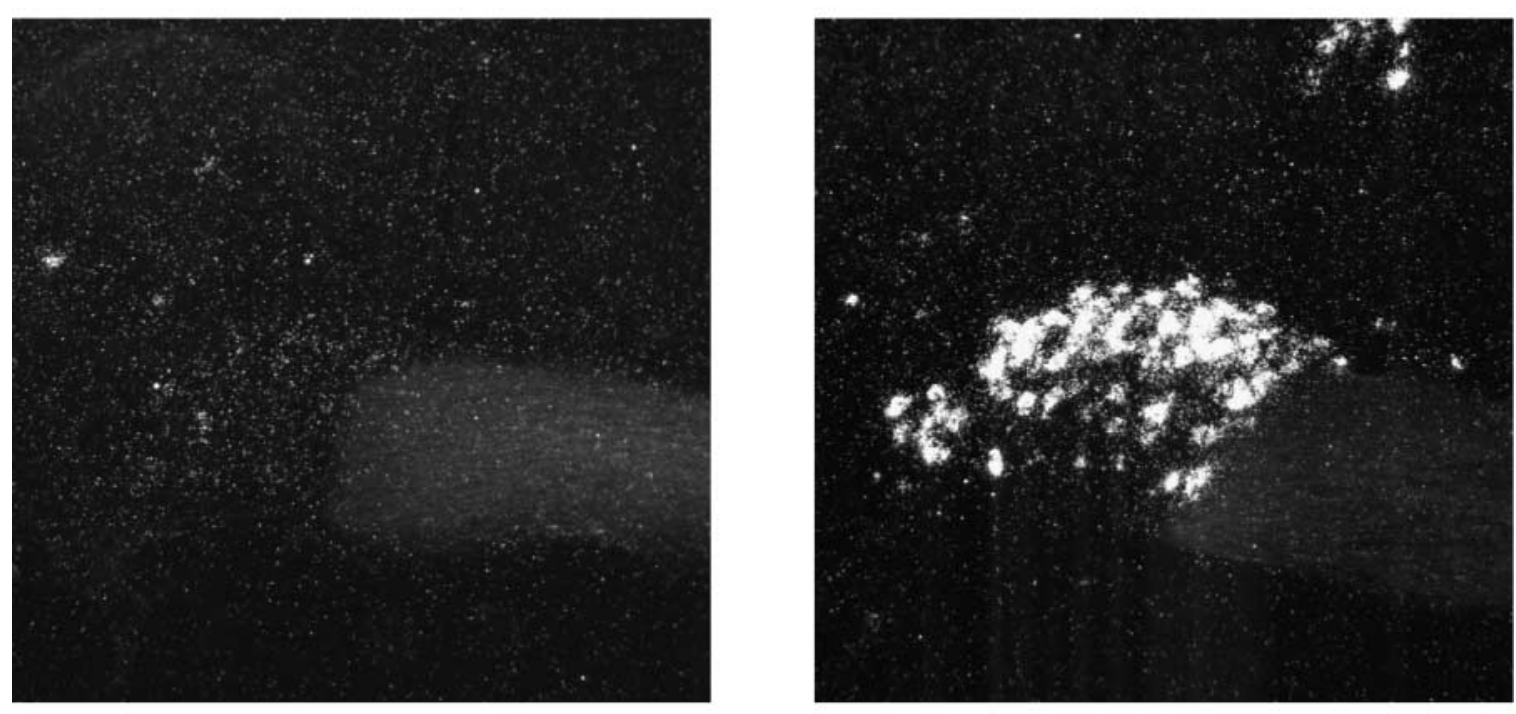

ADX



Non-diabetic



\section{Diabetic}

Figure 3 Dark field photomicrographs depicting CRF mRNA hybridization signal on the coronal brain sections (30 $\mu \mathrm{m}$ thick) taken at the level of the SON in rats with intact adrenal glands (top panels) or after adrenalectomy (ADX; bottom panels), nondiabetic (left panels), or diabetic (right panels). Ox, optic chiasm. The scale bar corresponds to $200 \mu \mathrm{m}$. 

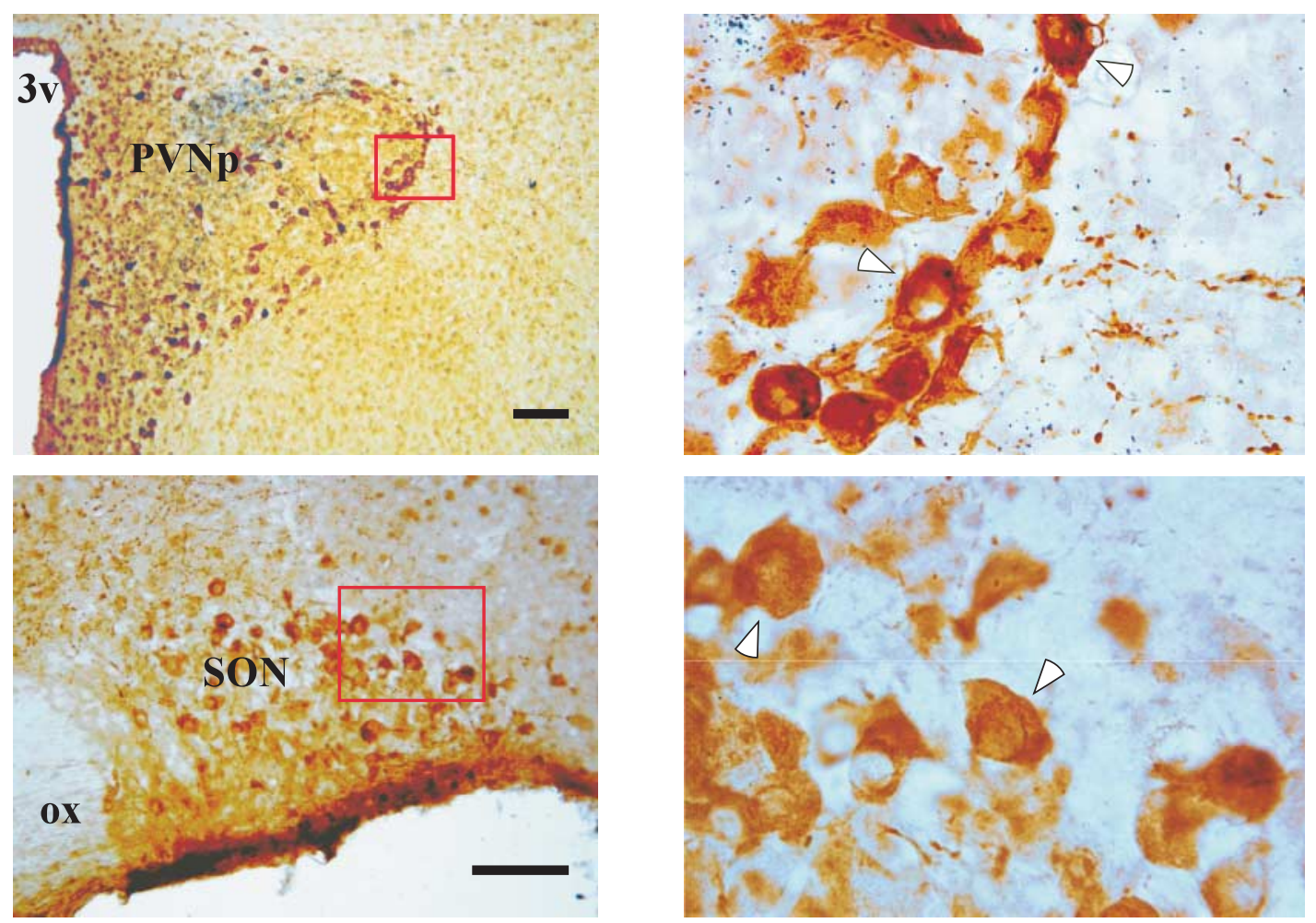

\section{Non-diabetic}
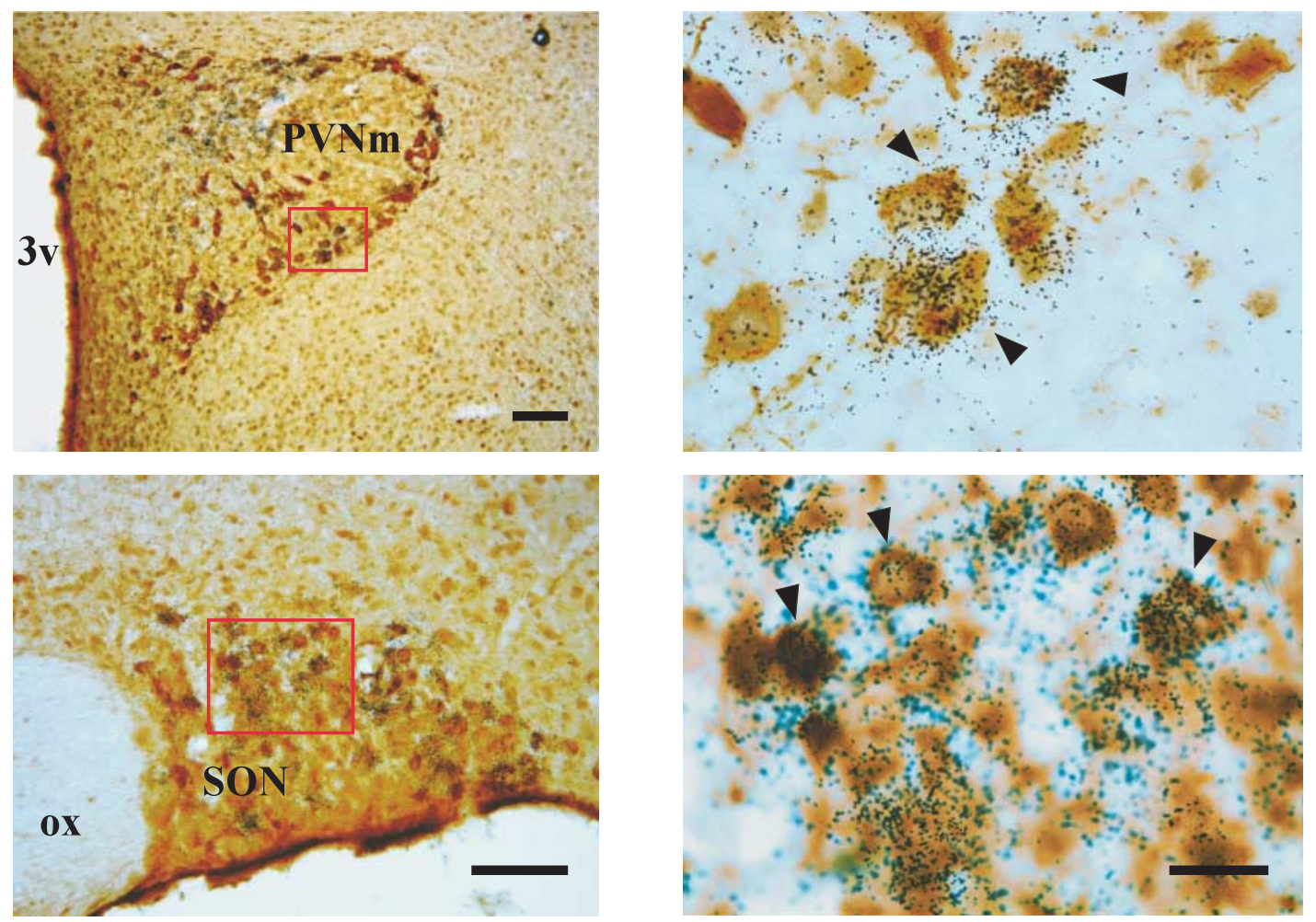

\section{Diabetic}




\section{Combination of immunocytochemistry with in situ hybridization}

Immunocytochemical detection of immunoreactivity for oxytocin (OT-ir) and arginine vasopressin (AVP-ir) was combined with detection of CRF mRNA in the PVN or SON to determine whether OT or vasopressin was colocalized with CRF in diabetic rats. Brain sections were first processed for immunocytochemical detection of OT-ir and AVP-ir using a conventional avidin-biotinimmunoperoxidase method. Briefly, brain slices were washed in sterile $50 \mathrm{mM}$ potassium PBS (KPBS) that was treated with diethylpirocarbonate. They were then incubated for $24 \mathrm{~h}$ at $4{ }^{\circ} \mathrm{C}$ with an OT or AVP antibody (rabbit polyclonal IgG; Star Technologies Inc., Minneapolis, MN, USA). The OT and AVP antibodies were used at a 1:1000 and 1:10 000 dilution respectively, in KPBS with heparin $(0 \cdot 25 \%)$, Triton X-100 $(0 \cdot 4 \%)$, and BSA $(2 \%)$. Following incubation at $4{ }^{\circ} \mathrm{C}$ with the first antibody, the brain slices were rinsed in sterile KPBS and incubated with a mixture of KPBS, Triton X-100, heparin, and biotinylated goat antirabbit IgG (1:1500 dilution; Vector Labs, Burlingame, CA, USA) for $60 \mathrm{~min}$. Sections were then rinsed with KPBS and incubated at room temperature for $60 \mathrm{~min}$ with an avidin-biotin-peroxidase complex (Vectastain ABC Elite Kit; Vector Labs). After several rinses in sterile Tris-HCl $(50 \mathrm{mM}, \mathrm{pH} 7 \cdot 6)$, the brain slices were allowed to react in a mixture containing sterile Tris, the chromagen 3,3'-diaminobenzidine tetrahydrochloride $(0.05 \%)$, and $1 \%$ hydrogen peroxide. Thereafter, tissues were rinsed in KPBS, mounted onto poly-L-sinecoated slides, desiccated overnight under vacuum, fixed in paraformaldehyde $(4 \%)$ for $30 \mathrm{~min}$, and digested for $30 \mathrm{~min}$ at $37^{\circ} \mathrm{C}$ with proteinase $\mathrm{K}$ $(10 \mu \mathrm{g} / \mathrm{ml}$ in $100 \mathrm{mM}$ Tris-HCl $(\mathrm{pH} 8 \cdot 0)$, and $50 \mathrm{mM}$ EDTA). Prehybridization, hybridization, and posthybridization steps were performed as described above except for the dehydration step, which was shortened to avoid decolorization of OT-ir or AVP-ir cell. After vacuum drying for $2 \mathrm{~h}$, sections were exposed on X-ray film, defatted in xylene, and dipped in the NTB2 nuclear emulsion. Slides were exposed for 7 days, developed in D19 developer for $3.5 \mathrm{~min}$ at $14^{\circ} \mathrm{C}$, and fixed in rapid fixer for $5 \mathrm{~min}$. Thereafter, tissues were rinsed in running distilled water for $1-2 \mathrm{~h}$, rapidly dehydrated through graded concentrations of alcohol, cleared in xylene, and coverslipped with DPX.

\section{Antisense ${ }^{35} \mathrm{~S}$-labeled cRNA probes}

The CRF cRNA probe was generated from the $1.2 \mathrm{~kb}$ EcoRI fragment of a rat CRF cDNA (Dr Mayo K, Northwestern University, Evanston, IL, USA) subcloned into a pGEM4 vector (Stratagene, La Jolla, CA, USA), and linearized with HindIII and EcoRI (Pharmacia Biotech Canada, Inc.) for antisense and sense probes respectively. The $\mathrm{CRF}_{1} \mathrm{R}$ cRNA probe was generated from a $1.3 \mathrm{~kb}$ PstI-PstI fragment of the rat prCRF PP1.3-BS cDNA (Dr Vale W, Peptide Biology Laboratory, The Salk Institute) subcloned into a pBluescript II-SK vector (Stratagene) and linearized with BamHI and HindIII to generate antisense and sense probes respectively. The rat $\mathrm{CRF}_{2} \mathrm{R}$ cRNA probe was prepared from a $275 \mathrm{bp}$ fragment of the $5^{\prime}$-region cDNA of the $\mathrm{CRF}_{2}$ receptor (Dr Lovenberg $\mathrm{T} \mathrm{W}$, Neurocrine Biosciences, Inc.) subcloned into a pBluescript SK+ vector (Stratagene) and linearized with EcoRI and RamHI for antisense and sense probes respectively. The radioactive antisense riboprobes were synthesized by incubation of $250 \mathrm{ng}$ linearized plasmids in $6 \mathrm{mM}$ $\mathrm{MgCl}_{2}, 40 \mathrm{mM}$ Tris $(\mathrm{pH} 7 \cdot 5), 10 \mathrm{mM} \mathrm{NaCl}, 10 \mathrm{mM}$ dithiothreitol, $0 \cdot 2 \mathrm{mM}$ ATP/GTP/CTP, and $\alpha_{-}{ }^{35} \mathrm{~S}$ UTP, 40 U RNase inhibitor (Promega), and 20 U SP6, T7 or T3 RNA polymerase for $\mathrm{CRF}, \mathrm{CRF}_{1} \mathrm{R}$, or $\mathrm{CRF}_{2} \mathrm{R}$ antisense probes for $60 \mathrm{~min}$ at $37^{\circ} \mathrm{C}$. The DNA templates were treated with $100 \mu \mathrm{l}$ DNAse solution ( $1 \mu \mathrm{l}$ DNAse, $5 \mu \mathrm{l}$ of $5 \mathrm{mg} / \mathrm{ml}$ tRNA, $94 \mu \mathrm{l}$ of $10 \mathrm{mM}$ Tris/ $10 \mathrm{mM} \mathrm{MgCl}_{2}$ ). The preparation of the riboprobes was accomplished through phenol-chloroform extraction and ammonium acetate precipitation. The specificity of each probe was confirmed by the absence of positive signal in sections hybridized with sense probe.

\section{Quantitative analyses of the hybridization signals}

The hybridization signals revealed on NTB2 dipped nuclear emulsion slides were analyzed and quantified under a light microscope (Olympus, BX50) equipped with a black and white video camera (Sony, XC-77) coupled to a Macintosh computer (Power PC 7100/66) using Image software (version 1.55 non-FPU, Wayne Rasband, NIH, Bethesda, MD, USA). The optical density (OD) of the hybridization signal was measured under dark field illumination. Brain sections were matched for rostrocaudal levels as closely as possible using the atlas of the rat brain (Paxinos \& Watson 1997). The OD for each specific region was corrected

\footnotetext{
Figure 4 Bright field photomicrographs demonstrating oxytocin immunoreactivity (OT-ir; brown staining) and CRF mRNA hybridization signal (silver grains) in the paraventricular hypothalamic nucleus (PVN) and SON in non-diabetic (four top panels) and diabetic (four bottom panels) rats with intact adrenal glands. The right panels are the high-magnification photomicrographs depicting neurons outlined by rectangles on the left panels. White arrowheads indicate some neurons displaying OT-ir only; black arrowheads indicate representative neurons coexpressing OT protein and CRF mRNA. Note the absence of CRF hybridization signal in the OT neurons in the magnocellular PVN and in the SON in non-diabetic rats. PVNp and PVNm are the parvocellular and magnocellular part of the PVN respectively; 3v, third ventricle; ox, optic chiasm. The scale bars correspond to $20 \mu \mathrm{m}$ for right panels and $100 \mu \mathrm{m}$ for left panels.
} 
for the average background signal, which was determined by sampling unlabeled area outside the areas of interest. When no hybridization signal was visible under dark field illumination, the brain structures of interest were outlined under bright field illumination and then subjected to densitometric analysis under dark field illumination. Saturation of the hybridization signal was avoided by the creation of the calibrate density profile plot for the strongest hybridization signals sampled for each region in every series. The system luminosity was then corrected so that for this strongest hybridization signals the reading OD did not exceed the half of the pixel value maximum, and this luminosity was conserved throughout the analysis of entire series. In the PVN (parvocellular and magnocellular parts), ODs were measured for each animal on two to three brain sections, taken between 1.6 and $2.0 \mathrm{~mm}$ caudal to bregma (Paxinos \& Watson 1997). In the SON and VMH, ODs were measured for each animal on four brain sections taken between $1 \cdot 3-1 \cdot 8 \mathrm{~mm}$ for SON and $2 \cdot 8-3 \cdot 3 \mathrm{~mm}$ for $\mathrm{VMH}$ caudal to bregma (Paxinos \& Watson 1997). Measurements were done on both left and right hemispheres. The values of the hemispheres and then those of the sections were averaged (four to eight measurements) to calculate individual scores. These scores were used to determine the mean \pm s.E.M. for each group.

\section{Plasma determinations}

The intracardial blood samples were taken in anesthetized rats immediately before the intracardial perfusion with saline. Plasma glucose was determined (glucose oxidase method) using a glucose analyzer (Beckman, Palo Alto, CA, USA). Insulin levels were determined by RIA (sensitivity, $0 \cdot 035 \mathrm{nmol} / \mathrm{l}$; interassay coefficient of variation, 9.2\%) using reagent kits from Incstar (Stillwater, MN, USA). Plasma corticosterone was determined by a competitive protein-binding assay (sensitivity, $0 \cdot 058 \mathrm{nmol} / \mathrm{l}$; interassay coefficient of variation, $9 \cdot 0 \%$ ) using plasma from a dexamethasonetreated female Rhesus monkey as the source of transcortin (Murphy 1967).

\section{Statistical analysis}

Results are expressed as the mean \pm s.E.M. for each group. A $2 \times 2$ ANOVA was used to examine the main and interaction effects of insulin status (I: non-diabetic, diabetic) and corticosterone status (C: sham-operated, $\mathrm{ADX})$ on the various dependent variables measured in this study. A posteriori comparisons between groups were realized using the Fisher's protected least squares difference test. Each experimental group included five to seven animals.

\section{Parvocellular PVN}

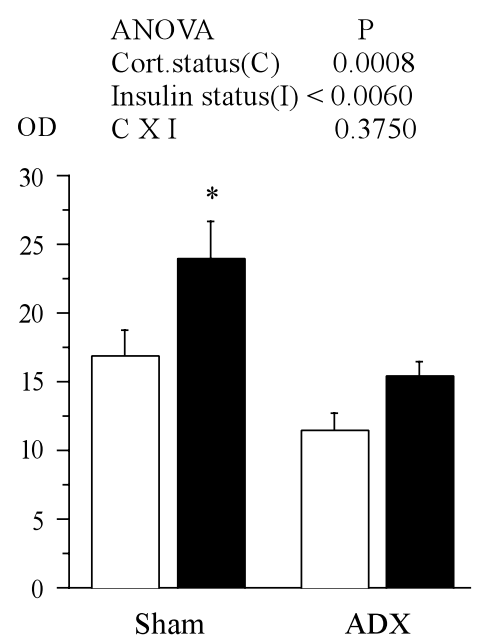

Magnocellular PVN

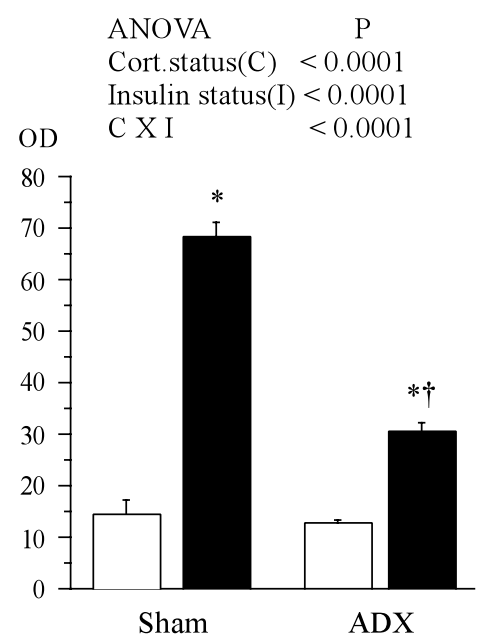

\section{SON}

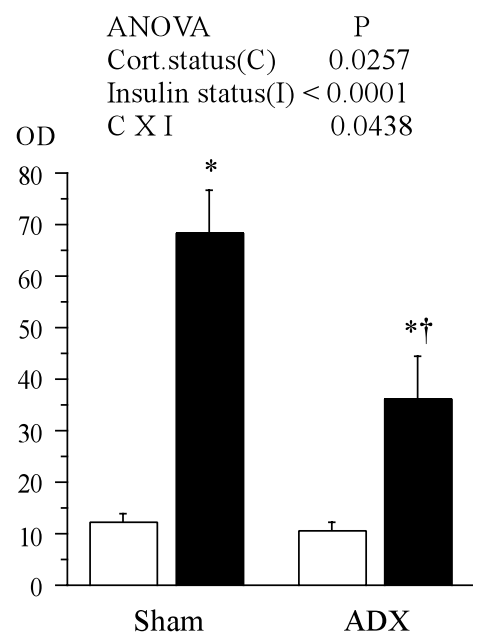

\footnotetext{
non-diabetic diabetic

Figure 5 The optical densities (ODs) of the hybridization signals of the $\mathrm{CRF}_{1} \mathrm{R}$ mRNA in the parvocellular and magnocellular parts of the paraventricular hypothalamic nucleus (PVN) and in the SON. The main and interaction effects of insulin status (I; nondiabetic or diabetic) and corticosterone status (C; sham-operated or adrenalectomized) were determined using $2 \times 2$ ANOVA, followed by a posteriori Fisher's posterior list of significant difference. *Significantly different from non-diabetic rats within the same adrenal status; ${ }^{\dagger}$ Significantly different from sham-operated rats within the same insulin status, $P<0 \cdot 05$.
} 


\section{Results}

\section{Body weight, weight of the white adipose tissue, food intake, and water intake}

The values in Table 1 show the different effects of diabetes or $\mathrm{ADX}$ on the $\mathrm{BW}$, BW gain, weight of epididymal WAT, and relative WAT/BW, FI, and WI in sham-operated and adrenalectomized non-diabetic or diabetic rats. The BW, BW gain, WAT weight, and WAT/BW were markedly lower in diabetic rats than in non-diabetic animals. The absolute value of diurnal FI appeared to be equivalent in STZ-treated and non-diabetic rats within the same adrenal status. However, when absolute FI measurements were corrected for BW differences, they revealed that in sham-operated groups, the diabetic rats consumed higher amount of food than did non-diabetic rats. Adrenalectomized rats consumed less food compared to the animals with intact adrenals. The WAT weight and WAT:BW ratio decreased in response to diabetes and ADX. STZ treatment significantly increased WI. This effect of STZ on WI was more important in sham-operated rats (sixfold increase) compared to ADX animals (twofold increase).

\section{Sham}
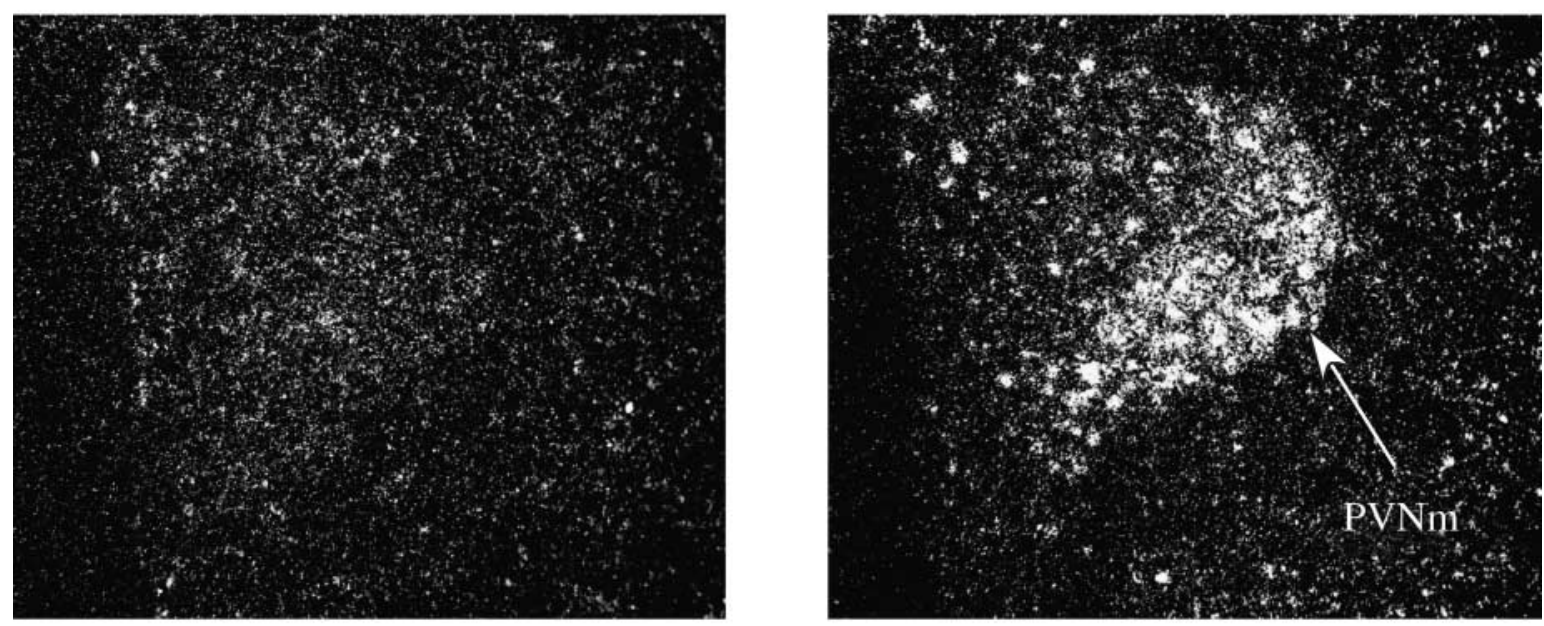

ADX

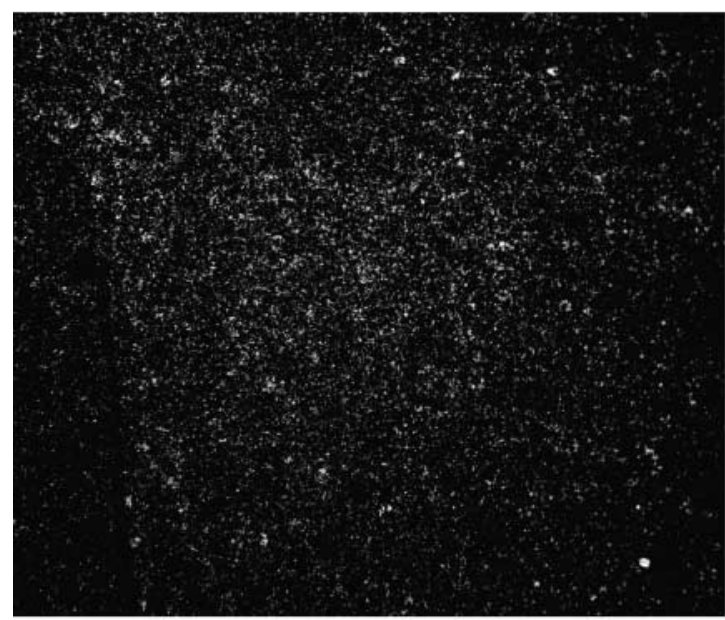

Non-diabetic

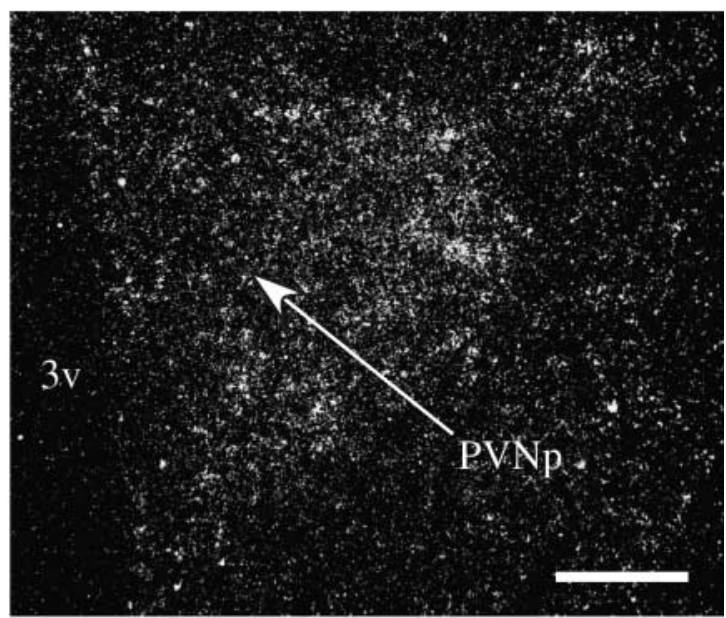

Diabetic

Figure 6 Dark field photomicrographs of coronal brain sections taken from the PVN, depicting $C_{\text {FF }}{ }_{1} R$ mRA. The brain sections (30 $\mu \mathrm{m}$ thick) were obtained from sham-operated (top panels) or adrenalectomized (ADX; bottom panels) non-diabetic (left panels) or diabetic (right panels) rats. PVNp and PVNm are the parvocellular and magnocellular parts of the PVN respectively; $3 \mathrm{v}$, third ventricle. The scale bar corresponds to $200 \mu \mathrm{m}$. 


\section{Plasma glucose, insulin, and corticosterone levels}

Plasma glucose levels were significantly higher in diabetic rats compared to non-diabetic animals, whereas ADX slightly decreased plasma glucose (Table 1). The STZ-treated rats had very low plasma insulin levels. There was a non-significant tendency for a reduction in plasma insulin after ADX. STZ resulted in a threefold increase in corticosterone levels in rats with intact adrenal glands.

\section{CRF MRNA}

CRF expression in the parvocellular part of the PVN was lowered and enhanced after respectively STZ and ADX (Figs 1 and 2). ANOVA revealed a significant effect of both corticosterone $(P=0 \cdot 001)$ and insulin $(P=0 \cdot 004)$ status on the expression of the CRF mRNA in the parvocellular PVN. In the magnocellular PVN (Figs 1 and 2) as well as in the SON (Figs 1 and 3), CRF expression was low in non-diabetic rats, but markedly

Sham
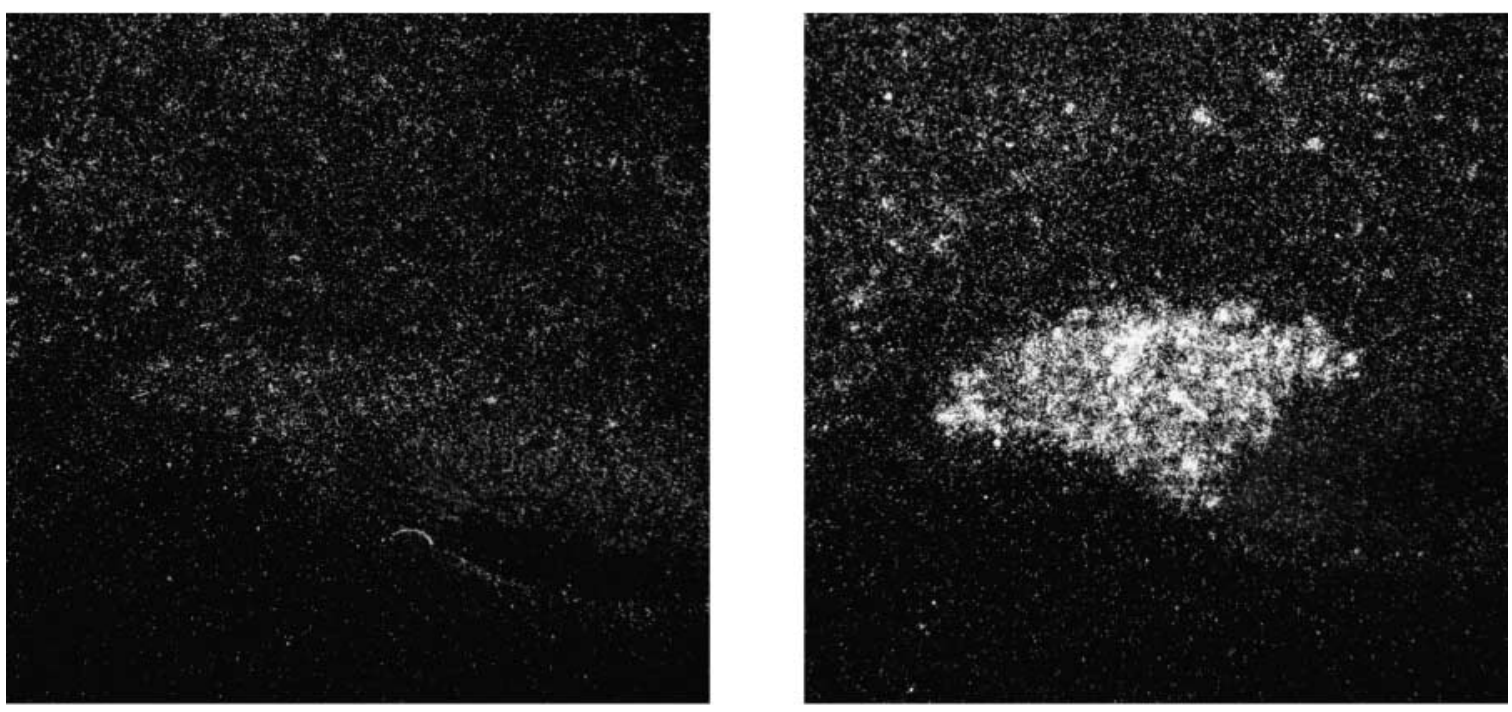

ADX

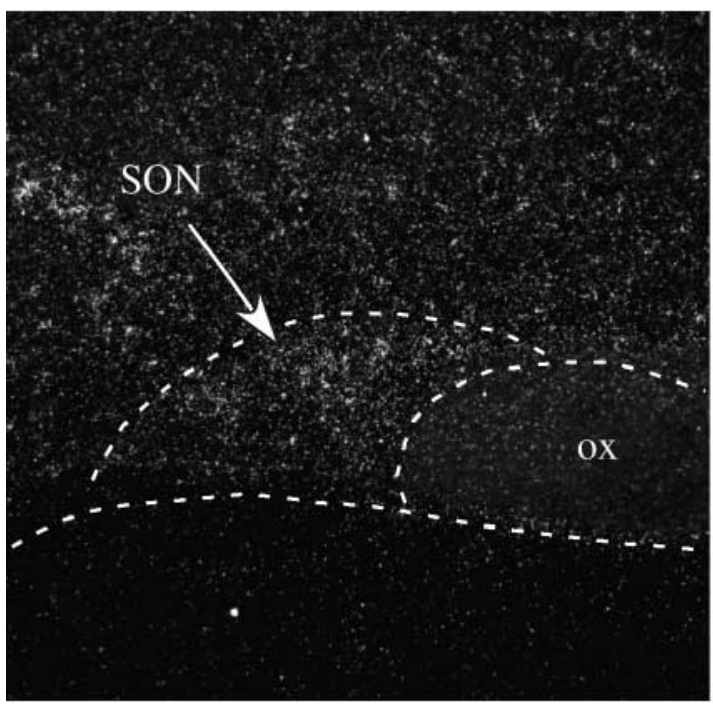

Non-diabetic

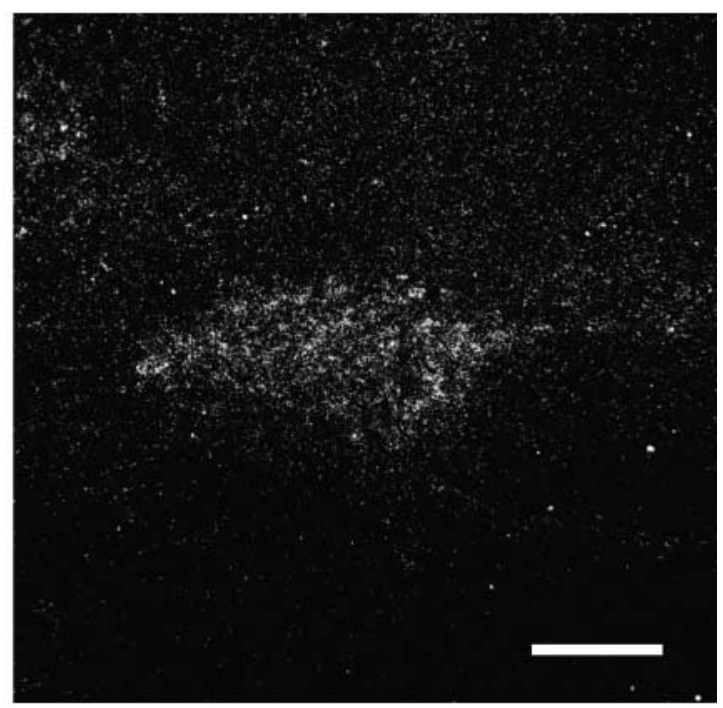

Diabetic

Figure 7 Dark field photomicrographs illustrating $\mathrm{CRF}_{1} \mathrm{R}$ hybridization signal on the coronal brain sections (30 $\mu \mathrm{m}$ thick) taken at the level of the SON in rats with intact adrenal glands (top panels) or after ADX (bottom panels), non-diabetic (left panels) or diabetic (right panels). ox, optic chiasm. The scale bar corresponds to $200 \mu \mathrm{m}$. 
increased in diabetic animals. ADX strongly enhanced CRF transcription in the parvocellular PVN of both non-diabetic and diabetic animals (Figs 1 and 2), however, it significantly decreased CRF transcript levels in the magnocellular PVN and SON in diabetic rats. Combination of immunohistochemistry for OT and AVP with in situ hybridization for CRF mRNA revealed that CRF expression in magnocellular neurons in diabetic rats was confined to oxytocinergic neurons (Fig. 4). Following STZ treatment, the majority of OT-ir cells in the PVN and SON coexpressed CRF mRNA. There was no colocalization of AVP-ir and CRF mRNA in either the PVN or the SON of diabetic and nondiabetic rats (data not shown).

\section{$\mathrm{CRF}_{1} R$ mRNA and $\mathrm{CRF}_{2} \mathrm{R}$ mRNA}

Diabetes induced the expression of the $\mathrm{CRF}_{1} \mathrm{R}$ in both the PVN and the SON. The $\mathrm{CRF}_{1} \mathrm{R}$ transcript was barely detectable in the PVN and SON of control non-diabetic rats. After $\mathrm{STZ}$ treatment, $\mathrm{CRF}_{1} \mathrm{R}$ mRNA expression was strongly induced in the magnocellular PVN (Figs 5 and 6 ) and in the SON (Figs 5 and 7). Also, levels of the $\mathrm{CRF}_{1} \mathrm{R}$ transcript moderately but significantly rose in the parvocellular part of the PVN (Figs 5 and 6). ADX partially blunted STZ-induced expression of $\mathrm{CRF}_{1} \mathrm{R}$ mRNA in the PVN and SON.

The expression of the $\mathrm{CRF}_{2} \mathrm{R}$ in the $\mathrm{VMH}$ was significantly lower in diabetic animals (Fig. 8). This reduction was not dependent on the corticosterone status and was seen in both, sham-operated and ADX diabetic rats (Fig. 9).

\section{Discussion}

The results of the present study clearly demonstrate an induction of $\mathrm{CRF}$ and $\mathrm{CRF}_{1} \mathrm{R}$ in the magnocellular part of the PVN and in the SON of STZ-treated rats. In contrast, the parvocellular part of the PVN of diabetic rats expressed less CRF mRNA. ADX significantly increased CRF expression in the parvocellular PVN independent of the insulin status and blunted CRF and $\mathrm{CRF}_{1} \mathrm{R}$ induction in the magnocellular PVN and SON of STZ-treated rats.

A significant decrease in CRF mRNA expression after STZ treatment in the parvocellular PVN is in agreement with previous reports (Sipols et al. 1995, Schwartz et al. 1997), which provide evidence for a decrease in the parvocellular CRF expression in diabetic rats despite increases in plasma ACTH levels and in adrenal gland weight. The reduction in CRF mRNA expression in the parvocellular PVN in uncontrolled diabetes most probably depends on the levels of plasma corticosterone (Sipols et al. 1995, Schwartz et al. 1997). Corticosterone levels increased by three times following STZ treatment and were accompanied with a decrease in parvocellular CRF expression. In contrast, ADX led to a strong activation of the CRF mRNA synthesis in the parvocellular neurons. Corticosterone replacement has been reported to dose-dependent reverse the ADXstimulating effects on the CRF PVN gene expression in diabetic rats (Schwartz et al. 1997).

The mechanisms responsible for the activation of the magnocellular system in animals with insulin deficiency has yet to be fully described, but seems to be associated with the hyperosmotic challenge resulting from the hyperglycemia that occur in uncontrolled diabetes mellitus (Musabayane et al. 1995). It is noteworthy that the CRF expression in the magnocellular neurons in diabetic rats was likely not attributable to normal saline drinking as sham animals, which were also provided with this saline, did not demonstrate any magnocellular expression of CRF. Furthermore, it is well known that normal saline does not alter plasma osmolality or hypothalamic CRF content (Imaki et al. 1992). In diabetic rats, the drinking of saline has been reported not to change plasma insulin levels, blood pressure, glomerular filtration rate, and kidney weight

\section{$\mathrm{VMH}$}

$\begin{array}{llc} & \text { ANOVA } & \text { P } \\ & \text { Cort.status(C) } & 0.0605 \\ \text { OD } & \text { Insulin status(I) } & 0.0003 \\ & \text { C X I } & 0.4870\end{array}$



Non-diabetic

Diabetic

Figure 8 The optical densities (ODs) of the hybridization signals of the $\mathrm{CRF}_{2} \mathrm{R}$ mRNA in the ventromedial hypothalamic nucleus (VMH). The main and interaction effects of insulin status (I; nondiabetic or diabetic) and corticosterone status (C; sham-operated or adrenalectomized) were determined using $2 \times 2$ ANOVA, followed by a posteriori Fisher's posterior list of significant difference. *Significantly different from non-diabetic rats within the same adrenal status. 
(Dai et al. 1994, Vallon et al. 1997). It is notable that the expression of CRF in the magnocellular neurons of diabetic rats was partially reversed by ADX.

As revealed through double labeling, CRF mRNA expression in the magnocellular PVN and SON was confined specifically to OT but not to AVP neurons. The mechanism for such selectivity in CRF expression within a particular subgroup of magnocellular neurons in diabetic rats is not clear. Uncontrolled diabetes apparently triggers the synthesis of both OT and AVP (Luo et al. 2002). The selectivity for CRF expression in OT-ir but not AVP-ir neurons has been reported in osmotic stress (Dohanics et al. 1990, Imaki et al. 2001a), whereas insulin-induced hypoglycemia promotes CRF and AVP colocalization (Paulmyer-Lacroix et al. 1994). The impact of an enhanced CRF expression in OT neurons is as yet undetermined. Magnocellular CRF may directly affect the adenohypophysis by means of local secretion from the magnocellular axons in passage through the external zone of the median eminence (Holmes et al. 1986). In addition, magnocellular CRF via the neurohypophysis may reach the circulation and directly stimulate the adrenal glands using the extrapituitary mechanisms (Fehm et al. 1988). It is not clear as to whether CRF can activate the release of OT, which could either activate or block the HPA-axis activity (Petersson et al. 1999, Windle et al. 2004, Laguna-Abreu et al. 2005) depending on various factors. At the level of anterior pituitary, OT has been reported to act as an ACTH secretagog, with significant effects seen at low concentrations (Schlosser et al. 1994). There is also evidence that endogenous brain OT enhances the long lasting, but not the acute HPA-axis response (Nakashima et al. 2002). In STZ rats, OT may be involved in the maintenance of the HPA-axis hyperactivity. Diabetic rats exhibit an enhanced basal HPAaxis activity but a blunted response to an acute CRF, ACTH, or dexamethasone test (Chan et al. 2002). Basal HPA axis may also be affected by magnocellular CRF that directly stimulates the AVP secretion through a paracrine mechanism at the level of neurohemal zone of the neurohypophysis (Alzein et al. 1984).

In order to better understand the central CRF pathways sensitive to insulin and corticosterone deficiencies, we examined the expression of CRF receptors in diabetic and adrenalectomized rats. Diabetic rats demonstrated a dramatic increase in $\mathrm{CRF}_{1} \mathrm{R}$ mRNA expression in the SON and magnocellular PVN, and a modest enhancement in the parvocellular PVN. The $\mathrm{CRF}_{1} \mathrm{R}$ is broadly expressed throughout the brain, but it is barely detected in the hypothalamic parvocellular and magnocellular neurons under basal conditions

Sham
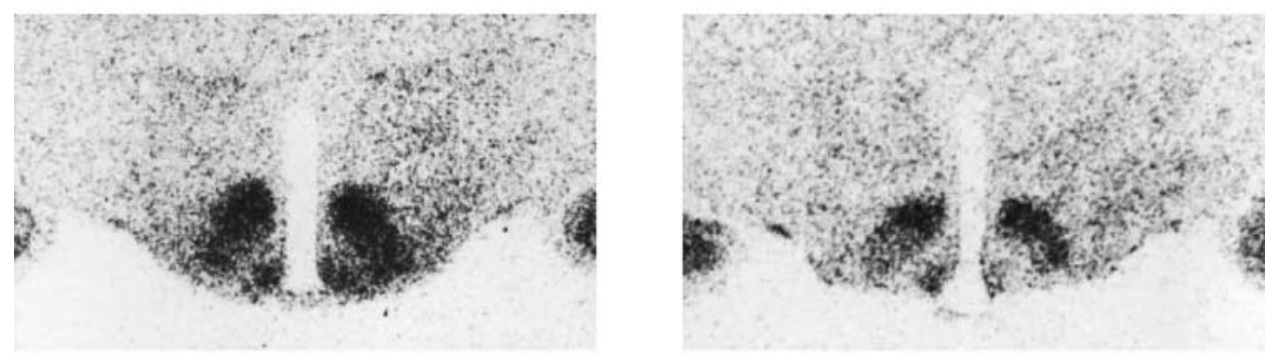

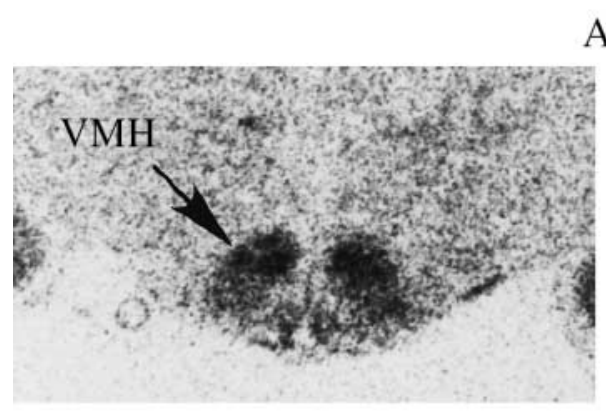

Non-diabetic

ADX

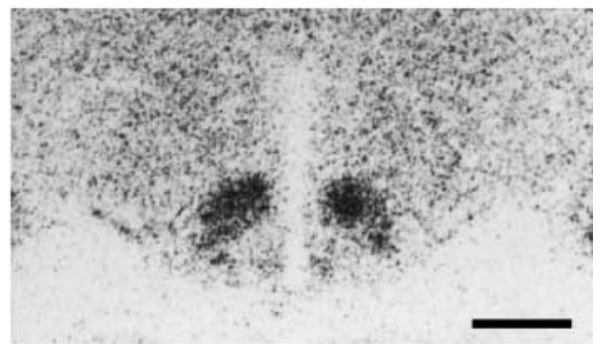

Diabetic

Figure 9 Film autoradiograms of coronal brain sections demonstrating $\mathrm{CRF}_{2} \mathrm{R}$ transcript at the level of the $\mathrm{VMH}$. The brain sections (30 $\mu \mathrm{m}$ thick) were obtained from sham-operated (top panels) or adrenalectomized (ADX; bottom panels) non-diabetic (left panels) or diabetic (right panels) rats. The scale bar corresponds to $1 \mathrm{~mm}$. 
(Perrin et al. 1993). However, the expression of the $\mathrm{CRF}_{1} \mathrm{R}$ in the parvocellular PVN has been reported to be triggered by different stressful conditions (Rivest $e t$ al. 1995, Richard et al. 1996, Timofeeva \& Richard 1997). The mechanism underlying $\mathrm{CRF}_{1} \mathrm{R}$ expression in the magnocellular neurons of diabetic rats is not yet clear, but it may involve CRF, which is also induced in the magnocellular system of these animals. Indeed, CRF may modulate its own biosynthesis as well as that of its type-1 receptor through an ultra-short positive feedback loop (Mansi et al. 1996, Imaki et al. 2001b).

The present study demonstrates the significant decrease in the expression of the $\mathrm{CRF}_{2} \mathrm{R}$ in the $\mathrm{VMH}$ of STZ-treated rats. The VMH is a brain region seemingly involved in the modulation of insulin secretion as ablation of the VMH led to increase in the parasympathetic tone to the pancreas and insulin oversecretion (Penicaud et al. 1996). It is, however, not clear whether a decrease in $\mathrm{CRF}_{2} \mathrm{R}$ at the levels of the $\mathrm{VMH}$ in diabetic rats is related to the control exerted by the VMH on insulin secretion. There is evidence that the $\mathrm{CRF}_{2} \mathrm{R}$ in the $\mathrm{VMH}$ mediates the anorectic effects of CRF (Richard et al. 2000, 2002). We have found a decrease in the $\mathrm{CRF}_{2} \mathrm{R}$ expression in food-deprived rats and in genetically obese Zucker rats (Richard et al. 1996, Timofeeva \& Richard 1997). Fasting rats, genetically obese rats, and diabetic animals are all hyperphagic and have impaired or low insulin signaling. In the brain, insulin inhibits feeding (Strack $e t$ al. 1995) and potentiates the anorexic effects of CRF (Richardson et al. 2002). The present results suggest that at least a part of insulin central effects may be mediated through its regulation of $\mathrm{CRF}_{2} \mathrm{R} \mathrm{VMH}$ expression.

In conclusion, the present study provides clear evidence that the systemic deficit in insulin and corticosterone results in opposite effects on the central expression of CRF and the $\mathrm{CRF}_{1} \mathrm{R}$. Uncontrolled diabetes led to a decrease in CRF expression in the parvocellular $\mathrm{PVN}$, but to the induction of $\mathrm{CRF}$ and $\mathrm{CRF}_{1} \mathrm{R}$ in the magnocellular system. In contrast, ADX increased parvocellular CRF, but significantly blunted STZ-induced activation of the magnocellular neurons. The levels of the $\mathrm{CRF}_{2} \mathrm{R}$ mRNA in the VMH were significantly lower in diabetic rats without any noticeable effects of ADX. The present results suggest that insulin and corticosterone deficiency have the opposite effects on the hypophysiotropic $\mathrm{CRF}$ and $\mathrm{CRF}_{1} \mathrm{R}$, whereas the expression of $\mathrm{CRF}_{2} \mathrm{R}$ is mostly related to the insulin, but not to the corticosterone, status. Alterations in the brain CRF system due to insulin deficiency may contribute to the hyperphagia, hyperdipsia, and the hyperactivity of the HPA axis in diabetes.

\section{Acknowledgements}

This work was supported by the Canadian Institutes of Health Research grant (to D R). The authors declare that there is no conflict of interest that would prejudice the impartiality of this scientific work.

\section{References}

Alzein M, Jeandel L, Lutz-Bucher B \& Koch B 1984 Evidence that CRF stimulates vasopressin secretion from isolated neurointermediate pituitary. Neuroendocrinology Letters 6 151-154.

Buwalda B, Deboer SF, Van Kalkeren AA \& Koolhaas JM 1997 Physiological and behavioral effects of chronic intracerebroventricular infusion of corticotropin- releasing factor in the rat. Psychoneuroendocrinology 22 297-309.

Cabanac M \& Richard D 1995 Acute intra-ventricular CRF lowers the hoarding threshold in male rats. Physiology and Behavior 57 705-710.

Chan O, Chan S, Inouye K, Vranic M \& Matthews SG 2001 Molecular regulation of the hypothalamo-pituitary-adrenal axis in streptozotocin-induced diabetes: effects of insulin treatment. Endocrinology 142 4872-4879.

Chan O, Inouye K, Vranic M \& Matthews SG 2002 Hyperactivation of the hypothalamo-pituitary-adrenocortical axis in streptozotocin-diabetes is associated with reduced stress responsiveness and decreased pituitary and adrenal sensitivity. Endocrinology 143 1761-1768.

Chan O, Inouye K, Akirav EM, Park E, Riddell MC, Matthews SG \& Vranic M 2005 Hyperglycemia does not increase basal hypothalamo-pituitary-adrenal activity in diabetes but it does impair the HPA response to insulin-induced hypoglycemia. American Journal of Physiology 289 R235-R246.

Dai S, Fraser H, Yuen VG \& McNeill JH 1994 Improvement in cardiac function in streptozotocin-diabetic rats by salt loading. Canadian Journal of Physiology and Pharmacology 72 1288-1293.

Dallman M, Akana SF, Bradbury MJ, Strack AM, Hanson ES \& Scribner KA 1994 Regulation of the hypothalamo-pituitary-adrenal axis during stress: feedback, facilitation and feeding. Seminars in Neuroscience 6 205-213.

DiTella PJ, Sodhi B, McCreary J, Arruda JA \& Kurtzman NA 1978 Mechanism of the metabolic acidosis of selective mineralocorticoid deficiency. Kidney International 14 466-477.

Dohanics J, Kovacs KJ \& Makara GB 1990 Oxytocinergic neurons in rat hypothalamus. Dexamethasone-reversible increase in their corticotropin-releasing factor-41-like immunoreactivity in response to osmotic stimulation. Neuroendocrinology 51 515-522.

Dube MG, Xu B, Kalra PS, Sninsky CA \& Kalra SP 1999 Disruption in neuropeptide $\mathrm{Y}$ and leptin signaling in obese ventromedial hypothalamic-lesioned rats. Brain Research 816 38-46.

Fehm HL, Holl R, Spath-Schwalbe E, Born J \& Voigt KH 1988 Ability of corticotropin releasing hormone to stimulate cortisol secretion independent from pituitary adrenocorticotropin. Life Science 42 679-686.

Holmes MC, Antoni FA, Aguilera G \& Catt KJ 1986 Magnocellular axons in passage through the median eminence release vasopressin. Nature 319 326-329.

Imaki T, Vale W \& Sawchenko PE 1992 Regulation of corticotropinreleasing factor mRNA in neuroendocrine and autonomic neurons by osmotic stimulation and volume loading. Neuroendocrinology 56 633-640.

Imaki T, Katsumata H, Miyata M, Naruse M, Imaki J \& Minami S $2001 a$ Expression of corticotropin releasing factor (CRF), urocortin and CRF type 1 receptors in hypothalamic-hypophyseal systems under osmotic stimulation. Journal of Neuroendocrinology 13 328-338. 
Imaki T, Katsumata H, Miyata M, Naruse M, Imaki J \& Minami S $2001 b$ Expression of corticotropin-releasing hormone type 1 receptor in paraventricular nucleus after acute stress. Neuroendocrinology 73 293-301.

King BM, Smith RL \& Frohman LA 1984 Hyperinsulinemia in rats with ventromedial hypothalamic lesions: role of hyperphagia. Behavioral Neuroscience 98 152-155.

Laguna-Abreu MT, Koenigkam-Santos M, Colleta AM, Elias PC, Moreira AC, Antunes-Rodrigues J, Elias LL \& Castro M 2005 Time course of vasopressin and oxytocin secretion after stress in adrenalectomized rats. Hormone and Metabolic Research 37 84-88.

Lovenberg TM, Liaw CW, Grigoriadis DF, Clevenger W, Chalmers DT, DeSouza EB \& Olsterdorf T 1995 Cloning and characterization of functionally distinct corticotropin-releasing factor receptor subtype from rat brain. PNAS 92 836-840.

Luo Y, Kaur C \& Ling EA 2002 Neuronal and glial response in the rat hypothalamus-neurohypophysis complex with streptozotocininduced diabetes. Brain Research 925 42-54.

Mansi JA, Rivest S \& Drolet G 1996 Regulation of corticotropinreleasing factor type 1 (CRF1) receptor messenger ribonucleic acid in the paraventricular nucleus of rat hypothalamus by exogenous CRF. Endocrinology 137 4619-4629.

Murphy BEP 1967 Some studies of the protein-binding of steroids and their application to the routine micro and ultramicro measurement of various steroids in body fluids by competitive protein-binding radioassays. Journal of Clinical Endocrinology and Metabolism 27 973-990.

Musabayane CT, Ndhlovu CE \& Balment RJ 1995 Renal fluid and electrolyte handling in streptozotocin-diabetic rats. Renal Failure 17 107-116.

Nakashima T, Noguchi T, Furukawa T, Yamasaki M, Makino S, Miyata S \& Kiyohara T 2002 Brain oxytocin augments stress-induced longlasting plasma adrenocorticotropic hormone elevation in rats. Neuroscience Letters 321 161-164.

Paulmyer-Lacroix O, Anglade G \& Grino M 1994 Insulin-induced hypoglycaemia increases colocalization of corticotrophin-releasing factor and arginine vasopressin mRNAs in the rat hypothalamic paraventricular nucleus. Journal of Molecular Endocrinology 13 313320 .

Penicaud L, Cousin B, Leloup C, Atef N, Casteilla L \& Ktorza A 1996 Changes in autonomic nervous system activity and consecutive hyperinsulinaemia: respective roles in the development of obesity in rodents. Diabetes and Metabolism 22 15-24.

Paxinos G \& Watson C 1997. The Rat Brain in Stereotaxic Coordinates, San Diego: Academic Press.

Perrin MH, Donaldson CJ, Chen R, Lewis KA \& Vale WW 1993 Cloning and functional expression of a rat brain corticotropin releasing factor (CRF) receptor. Endocrinology 133 3058-3061.

Petersson M, Hulting AL \& Uvnas-Moberg K 1999 Oxytocin causes a sustained decrease in plasma levels of corticosterone in rats. Neuroscience Letters 264 41-44.

Richard D, Rivest R, Naïmi N, Timofeeva E \& Rivest S 1996 Expression of corticotropin-releasing factor and its receptors in the brain of lean and obese Zucker rats. Endocrinology 137 4786-4795.

Richard D, Huang Q \& Timofeeva E 2000 The corticotropinreleasing hormone system in the regulation of energy balance in obesity. International Journal of Obesity and Related Metabolic Disorders 24 S36-S39.

Richard D, Lin Q \& Timofeeva E 2002 The corticotropin-releasing factor family of peptides and CRF receptors: their roles in the regulation of energy balance. European Journal of Pharmacology 440 189-197.

Richardson RD, Omachi K, Kermani R \& Woods SC 2002 Intraventricular insulin potentiates the anorexic effect of corticotropin releasing hormone in rats. American Journal of Physiology 283 R1321-R1326.

Rivest S, Laflamme N \& Nappi RE 1995 Immune challenge and immobilization stress induce transcription of the gene encoding the CRF receptor in selective nuclei of the rat hypothalamus. Journal of Neuroscince 15 2680-2695.
Rothwell NJ 1990 Central effects of CRF on metabolism and energy balance. Neuroscience and Biobehavioral Reviews 14 263-271.

Sawchenko PE \& Swanson LW 1985 Localization, colocalization, and plasticity of corticotropin-releasing factor immunoreactivity in rat brain. Federation Proceedings 44 221-227.

Sawchenko PE, Brown ER, Chan RKW, Ericsson A, Li HY, Roland BL \& Kovacs KJ 1996 The paraventricular nucleus of the hypothalamus and the functional neuroanatomy of visceromotor responses to stress. Progress in Brain Research 107 201-222.

Schlosser SF, Almeida OF, Patchev VK, Yassouridis A \& Elands J 1994 Oxytocin-stimulated release of adrenocorticotropin from the rat pituitary is mediated by arginine vasopressin receptors of the Vlb type. Endocrinology 135 2058-2063.

Schwartz MW, Strack AM \& Dallman MF 1997 Evidence that elevated plasma corticosterone levels are the cause of reduced hypothalamic corticotrophin-releasing hormone gene expression in diabetes. Regulatory Peptides 72 105-112.

Scribner KA, Walker CD, Cascio CS \& Dallman MF 1991 Chronic streptozotocin diabetes in rats facilitates the acute stress response without altering pituitary or adrenal responsiveness to secretagogues. Endocrinology 129 99-108.

Simmons DM, Arriza JL \& Swanson LW 1989 A complete protocol for in situ hybridization of messenger RNAs in brain and other tissues with radiolabeled single-stranded RNA probes. Journal of Histotechnology 12 169-181.

Sipols AJ, Baskin DG \& Schwartz MW 1995 Effect of intracerebroventricular insulin infusion on diabetic hyperphagia and hypothalamic neuropeptide gene expression. Diabetes 44 147-151.

Strack AM, Sebastian RJ, Schwartz MW \& Dallman MF 1995 Glucocorticoids and insulin: reciprocal signals for energy balance. American Journal of Physiology 37 R142-R149.

Timofeeva E \& Richard D 1997 Functional activation of CRH neurons and expression of the genes encoding CRH and its receptors in food-deprived lean $(F a /$ ? $)$ and obese $(f a / f a)$ Zucker rats Neuroendocrinology 66 327-340.

Vale W, Spiess J, Rivier C \& Rivier J 1981 Characterization of a 41-residue ovine hypothalamic peptide that stimulates secretion of corticotropin and beta-endorphin. Science 213 1394-1397.

Vallon V, Kirschenmann D, Wead LM, Lortie MJ, Satriano J, Blantz RC \& Thomson SC 1997 Effect of chronic salt loading on kidney function in early and established diabetes mellitus in rats. Journal of Laboratory and Clinical Medicine 130 76-82.

Vaughan J, Donaldson C, Bittencourt J, Perrin MH, Lewis K, Sutton S, Chan R, Turnbull AV, Lovejoy D, Rivier C et al. 1995 Urocortin, a mammalian neuropeptide related to fish urotensin I and to corticotropin-releasing factor. Nature 378 287-292.

Viau V \& Sawchenko PE 2002 Hypophysiotropic neurons of the paraventricular nucleus respond in spatially, temporally, and phenotypically differentiated manners to acute vs. repeated restraint stress: rapid publication. Journal of Comparative Neurology 445 293-307.

Will PC \& Barnett ME 1983 A sugar and electrolyte drinking solution for long-term maintenance of adrenalectomized rats. Laboratory Animal Science 33 172-174.

Windle RJ, Kershaw YM, Shanks N, Wood SA, Lightman SL \& Ingram CD 2004 Oxytocin attenuates stress-induced c-fos mRNA expression in specific forebrain regions associated with modulation of hypothalamo-pituitary-adrenal activity. Journal of Neuroscience 24 2974-2982.

Received 29 March 2006

Accepted 31 May 2006

Made available online as an Accepted Preprint

16 June 2006 